\title{
THE DUNDEE MEETING OF THE BRITISH ASSOCIATION
}

\section{General Arrangements}

$\mathrm{P}$ REPARATIONS for the Dundee Neeting of the British Association, which will open on August 30, aro in their final stage. There are indications that fear for the international situation is keeping a few visiting members away, but powerful efforts are being made in Dundee to secure the support of a strong body of local members such as is always anticipated at a Scottish meeting.

The main outlines of the programme have been announced long ago, and the activities of the sections are given under their own headings, but there are certain new features to bo mentioned here. Tho evening lecture on "Science and Social Pioneering", which Dr. Isaiah Bowman, president of Johns Hoplins University, will deliver, will be the first of a new series furnishing outward evidence of the intimate relations between the British and American Associations, which were so happily strengthened during the meeting at Cambridge last year. This series will be known as the British and American Association Lectures, a title which, if something cumbrous, has at least the merit of self-explanation. A British lecturer will be heard at an American Association meeting next year, and so thereafter, in alternate years at future meetings of the two Associations, this invaluable contact is intended to be maintained.

The new Division for the Social and International Relations of Science, created by the General Com. mittee of the Association last year, seems already to have established itself firmly. In case it should be feared that its potential field is beyond the scope of the Association's work, it may be said at once that there is no evidence of this: the outlook of the Association (taken as. a whole) is wide, and its mechanism elastic, and the new Division is in direct line of descent from the intentions of those who founded the Association more than a century ago. It will be evident from the transactions of the Division at Dundee that through it the Association is establishing contacts with other organizations which otherwise might have been neglected. The Division will hold three sessions, at which there are to be discussed an interim report on an inquiry into the organization of research in Britain, in which the Division is associated with PEP (Political and Economic Planning); population problems; international intellectual co-operation, introduced by Prof. Gilbert Murray; and nutrition, introduced by Sir John Orr. The Division has also arranged the Sunday evening lecture requested by the local executive in Dundee, which will be given by Sir Richard Gregory as chairman, on "Contacts of Religion and Science"; the public as well as members of the Association being admitted.

A third unusual feature in the programme of the meeting, though not without precedent, is found in the two special sessions dealing with jute, the material (it need scarcely be said) of one of Dundee's staple industries. Every scientific aspect of this material and the industry associated with it will be dealt with by experts, and the Textile Institute will collaborate in publishing the results.
The familiar programme and daily time-table will appear in a new guise. Its pages are increased to correspond in width (though not in depth) with those of the forthcoming quarterly form in which the annual report will be published in future. Moreover, the Journal of sectional transactions, containing abstracts of papers, will appear within the same covers and not as a separate publication, an arrangement, carried out not without heart-searching on the part of the administration, which should make for the general convenience. The new quarterly, of which the first number will appear at the end of October, will bear the title of The Adrancement of Science, a name hitherto attached to the collection of presidential addresses which has appeared for some years at the time of the meeting. This collection will now be discontinued, but in its place separates of the various addresses will be on sale at the meeting.

Entertainments detailed in the programme, while nowise overwhelming it, fully exemplify Scottish hospitality, notably the generous number of garden parties to be given by private hosts. The Corporation and the University College both entertain, as is customary, as also do the Dundee Harbour Trustees with a river trip. The Eastern Club, the University College Students' Union, the Dundeo Rotary Club, the Dundee Medical Club and the Forfarshire Medical Association, the Overseas League, and, it scarcely need be added, several famous golf clubs, including the Royal and Ancient of St. Andrews, all offer hospitality in various forms. Finally, masonic members of the Association will find very. special interest in a meeting arranged for them by the Dundee St. Mary Lodge, to exemplify a working of the Scottish Constitution.

The reports of the Council, the Down House Committee, and the Division for the Social and International Relations of Science, which will be presented to the General Committee, cover a range of incidental interests from the safeguarding of native tribes in Australia to that of the green belt around London, and from the possibility of a future annual meeting in Brighton to that of scientific delegations to the West Indies and Southern Rhodesia. It is no matter for wonder that the general treasurer in a recent appeal, and again in his forthcoming report, has asked for extended support for the Association by way of membership "from all those who appreciate the benefits that science confers and wish to aid the Association in discharging its function of the advancement of science".

\section{Sectional Programmes}

\section{Section A (Mathematical and Physical SCIENCES)}

GECTION A (Mathematical and Physical Sciences) $S$ has for many years had two sub-sections, one for mathematics and the other for cosmic physics, and each of them this year has some interesting discussions to offer. On the Saturday, there will be a discussion on "The Teaching of Mechanics", opened by Prof. E. A. Milne and continued by speakers representing Scottish and English schools and 
universities. Although the meeting is not a joint one, it is hoped that the choice of day will permit some members of Section $\mathrm{L}$ to attend and to take part in the open discussion. In cosmic physics, a discussion on solar-terrestrial relationships, to be opened by Prof. E. V. Appleton, promises much of interest, as also does one on the surface temperatures of stars.

It is not to be thought that the only matters of interest are those pertaining to the special interests of the subsections (though these are not so specialized as to be unintelligible to the ordinary member), for the main section shows a judicious blend of 'new' and 'classical' (or 'applied') physics, which should interest many. Starting on Thursday with electron optics and the presidential address by Mr. R. S. Whipple on "Instruments in Science and Industry", the former of which is 'electronic physies' but of wide everyday application, the section proceeds on Friday to artificial radioactivity, and on Monday to the theoretical but applied subject of "High-Speed Flight", and thence on Tuesday to high temperature physics, the programme of which is largely devoted to papers from the National Physical Laboratory and from laboratories of the steel-making industry. In the course of this session, a coloured film will be shown to illustrate some of the physical problems of modern steel malking.

\section{Section B (Chemistry)}

7 HE proceedings of Section B will begin with the presidential address by Prof. E. K. Rideal on "Film Reactions as a Now Approach to Biology", and the rest of the day will be devoted to a joint discussion with Section I on "Tissue Respiration", to be opened by Prof. R. A. Peters. Dr. Mrlcolm Dixon will deal with catalysis in tissue respiration (catatorulin) and Dr. H. Theorell (Stockholm) with the flavoproteins. After an account of cytochrome and similar compounds by Prof. D. Keilin, Dr. F. Dickens will consider the interpretation of intermediary metabolism from measurement of tissue respiration, and Dr. J. H. Quastel that of narcosis. Dr. S. Ochoa will deal with carbon dioxide evolution and cocarboxylase. Prof. H. S. Raper will discuss the control of tissue respiration, and other aspects of the subject will be presented in discussion by Dr. D. E. Green, Sir F. Gowland Hopkins, Dr. H. A. Krebs, Dr. T. Mann and Dr. E. P. Poulton.

A discussion on "Light Alloys" will be opened by Dr. C. H. Desch, who will speak of their growing importance and will refer in particular to their mechanical strength and to their resistance to corrosion. Dr. A. G. C. Gwyer will discuss the constitution of aluminium alloys and Mr. WV. C. Devereux will describe the controls of production of light alloys, including spectrographic analysis and the X-ray control of their thermal and mechanical treatment. Their industrial uses will be dealt with by Prof. A. von Zeerleder. An exhibition illustrating the uses of light metals and alloys, with a research section, will be open throughout the meeting.

Progress in physical chemistry is largely dependent on the development of new technique. Not only does such technique help to solve specific problems unassailable by the older methods, but it also opens up entirely new lines of investigation. This topic will form the subject of a discussion in which new methods and their bearing on problems connected with the mechanism of chemical reactions will be described. Radioactive and non-radioactive indicators ("labelled atoms') will be dealt with by Prof. S. Sugden and Prof. W. F. K. Wynne-Jones respectively. Dr. M. Ritchie will discuss reactions of free atoms; Prof. T. Alty accommodation coefficients, and Dr. H. W. Melville will describe recent technique in photochemistry.

At the last Dundee meeting of the British Association in 1912 Prof. A. McKenzie opened a discussion on the migration of groups and dealt especially with the Walden rearrangement. During tho quarter of a century which has elapsed, the Dundee school under his leadership has greatly advanced our knowledge in this field. On the present occasion, Prof. McKenzie and Dr. R. Roger will open a discussion on intramolecular change involving the migration of groups, and will give an account of their work on deamination and dehydration involving semi-pinacolinic rearrangements in which optically active alcohols and glycols have been used. Contributions will also be made by Prof. MI. Tiffeneau (Paris), Dr. S. F. Birch, who will deal with the catalytic isomerization of paraffins, Dr. A. K. Mills and Dr. T. S. Stevens.

A special feature of the meeting will bo a two-day discussion on jute, tho principal industry of Dundee, including chemical and physical as well as economic aspects of the subject. In this connexion a compre. hensive exhibition will be open throughout the meeting. Two popular lectures will bo given. Dr. D. A. Spencer will deal with colour photography and Dr. H. W. Melville will give an experimental lecture on the methods of producing light.

By kind invitation of the University Court, a visit will bo made to the University of St. Andrews, and visits to jute-spinning mills and Messrs. Moncrieff's glass works at Perth are being arranged. The usual sectional dinner will be held. The following chemists have accepted the Council's invitation to attend as foreign guests of the Association : Dr. H. Theorell (Stockholm), Prof. Nlarc Tiffeneau (Paris) and Prof. A. von Zeerleder (Zurich).

\section{Section C (Geology)}

THE programme of Section C (Geology) will, for the most part, be devoted to Scottish geology. Prof. H. H. Read has taken as tho title of his presidential address "Metamorphism and Igneous Action". $\mathrm{He}$ has spent much time in the study of this subject in the Highlands and elsewhere, and this summary of his views will be awaited with interest.

Discussions are to be held on the raised beaches of the Forth and Tay and on the boundary between the Carboniferous and the Old Red Sandstone. These are matters of considerable importance to geologists working in Scotland, and the contributors are largely drawn from the Scottish branch of the Geological Survey.

A number of short individual papers will bo presented. These will include: Prof. Innes on the geology of the Dundee district; Dr. J. Pringle on the discovery of Cambrian fossils in the Highland Border Series, an important advance in the study of these rather problematical rocks; Dr. M. Macgregor on the buried channel of the Forth, with Dr. Pringle on the Carboniferous rocks of Bridge of Awe and with Prof. J. Ritchie on remains of reindeer from the glacial deposits of Glasgow; Dr. T. S. Westoll on the fish fauna of the 'Caledonian' Old Red Sandstone; Prof. W. T. Gordon on a new type of seed from the Carboniferous rocks of Tantallon; Dr. E. Dix on the Coal Measures of Warwickshire and with Mr. W. D. Ware, on those of Pembrokeshire; 
Dr. A. Lamont on antidunes in geology; MIr. E. H. Davison on the solubility of rocks and Mr. F. IV. Anderson on algal limestones in east Fife and on ostracod zones in the Wealden and Purbeck Beds.

\section{SeCtion D (Zoology)}

D ROF. J. RITCHIE'S presidential address to Section D is entitled "Perspectives in Evolution". Tro discussions have been arranged by the Section. The first of these will cover various aspects of parthenogenesis. Prof. A. Vandel, the distinguished French authority on this subject, will open the discussion, Prof. Peacock will give a review of recent researches in experimental parthenogenesis, and Dr. Sanderson and Miss Malcolm (two workers from Prof. Peacock's laboratory) will contribute papers on the cytological aspects of parthenogenesis in snails and sawflies.

The second discussion will deal with the biology of salmon and trout, and, in the six papers arranged under this heading, a résumé of our present know. ledge of the migratory habits, homing instinct, food and sexual phases of these fishes will be given. Mr. Menzies, of the Scotch Fishery Board, will open the session, and other speakers include Prof. Orton, Mr. R. M. Neill and Mr. MacFarlane. Mr. D. F. Leney will contribute an account of modern hatchery methods for salmon and trout.

Dr. Fraser Darling will give a semi-popular lecture on the grey seal in which will bo included a summary of his recent researches on the behaviour and habits of the colony of seals on North Rona. Prof. Brambell and $\mathrm{Mr}$. H. A. Cole will describo a new ciliary organ found in enteropneusts which suggests affinities with the hypophysis of higher vertebrates and adds further evidence for the chordate affinities of the Hemichorda. Dr. Worthington will outline the develop. ments in research on fresh waters which have been inaugurated at the Freshwater Biological Station at Wray Castle.

There is to be an exhibition of biological films produced by the Strand Film Zoological Production, Ltd., Gaumont British Instructional Films, Ltd., and Associated British Film Distribution, Itd. Sectional excursions have been arranged to Glen Doll, the Field Station of the Department of Natural History at University College, Dundee, to the Perth Museum, and to the Silver Fox Farm of Mr. J. B. A. Mackenzie at Balbeggie.

\section{Section E (Geography)}

CECTION E (Geography) at Dundee will this year depart from precedent in that it will not open its meetings with the presidential address. Instead the first morning will be given to certain urban studies of Scotland and to a joint discussion with many other sections on tho proposed National Atlas. This latter proposal came before the Section at Cambridge and received general support. Since then a representative committee has been at work on the scheme, and its report will form the basis of the discussion. In the afternoon there will be two papers dealing with recent developments in the Ordnance Survey,

On Friday Mr. A. Stevens will deliver his presidential address, there will be one paper by Mr. Linton suggesting a new idea in the evolution of some of the Scottish rivers, and the local secretary, Dr. J. F. Scott, will give a preliminary account of the sectional excursions.

The excursions begin on Friday afternoon with a visit to the city of Dundee and to the Hillbank Linen Works. On the following day the Section will make a circular tour of the Fife peninsula, and on Sunday a visit will be made to part of the Highlands. Another excursion, on Tuesday, will give opportunity to study the agricultural geography of the Carse of Gowrie.

On Monday all papers deal with topics or regions which are outside Great Britain. Prof. T. M. Knox will raise some important points concerning the future of the palm oil industry in West Africa. Dr. N. Friberg, a foreign guest of the Association, will describe highway developments in Sweden. The Spanish zone in Morocco, the great basin of North America, and current movements of population in Eire are the subjects of the remaining papers.

On Tuesday, apart from one paper on the geography of Cheshire at the time of the Domesday Survey, the general topics are more closely related to Dundee or its neighbourhood. Thus one paper deals with population changes in the Lower Tay valley since 1755, and another discusses the geographical background of Scottish sea-borne trade in the eighteenth century. Dr. Snodgrass, whose studies of the agricultural geography of Scotland are well-known, will make comparisons of population density and agricultural typo in Britain and the Continent.

The meetings of the Section will end on Wednesday morning with two papers on subjects of physical geography, in one of which MIr. WV. V. Lewis will further develop his views on plucking as a factor in glacial valley erosion.

The programme of the Section covers a wide field, and apart from its general interest affords many indications of the way in which geography plays a part in current problems. It is hoped that this sido of the Section's activities will make an appeal to those members of the Association who will be natur. ally interested in the new Division for Social and International Relations of Science.

\section{Section F (Economics)}

RY the nature of its subject, the work of Section F (Economics) is essentially concerned with public welfare. It is current events which largely decide the aspects to be discussed. Last year unemployment and the trade cycle occupied the first place. For the Dundee meeting, a number of the papers concern urgent Scottish problems. There aro to bo papers on housing in Scotland, on the finance of Scottish Local Government, on the finance of now enterprises in Scotland, and on the economy of the crofting districts. Lord Douglas Hamilton will open a special afternoon session on the problem of the distressed areas, and the various measures taken to assist them.

Although the name of Dundee has always been associated with the jute industry, it has been the home of some financial activities of more than local importance. There will be a paper on the Dundee Investment Trusts. 'Three problems of 'planning' will como up for discussion-the localization of industry, tho economics of urban decentralization, and the consequences of the legislation concerning the coal-mining industry. In contrast to these detailed topics, $\mathbb{\Omega}$ whole morning will be given up to the discussion of the theory and problems of socialism, in its national and international aspects. It is perhaps a significant sign of the times that the Presidential address by Prof. H. O. Meredith will be on Rates and Taxes. 


\section{Section G (ENGINeERING)}

$\mathrm{T}$ HE presidential address to the Engineering Section will be delivered by Mr. H. E. Wimperis, who was for many years director of scientific research at the Air Ministry, and has recently been in Australia and New Zealand to advise those Governments upon the establishment of aeronautical research organizations. The subject of his address will be the "Future of Flying". Another item of great aeronautical interest will be a paper to be read by Major R. $H$. Mayo describing his composite aircraft which is under trial by the Air Ministry and Imperial Airways. The paper will be followed by a discussion which will be opened by a representative of Messrs. Shorts, who have built the trans-Atlantic flying boats, and a representative of Sir Alan Cobham, who has developed a system of flight refuelling.

The Section has during several years given careful consideration to the training of engineers, particularly in university courses. The matter was dealt with last year by Prof. R. V. Southwell in his presidential address and afterwards a questionnaire was circulated to a large number of practising engineers and firms who employ university graduates. A very large number of answers have been received, and these will be shortly reviewed by Prof. Willis Jackson who has been mainly responsible for the work.

An important paper will be read by Prof. R. G. H. Clements on the design of roads. There will be a number of other papers, and the Section will repeat its experiment of last year by including five short papers by junior engineers, each of whom will be allowed thirty minutes for his paper and the discussion which will follow it.

\section{Section H (ANTHROPOlOGY)}

A CCORDING to custom, the programme has been arranged so that the various branches of the study of man aro fairly represented. The section has this year restricted the number of papers to be read, in order that there may be adequate time for discussion. Prof. W. E. Le Gros Clark will give the presidential address (Friday) on "The Scope and Limitations of Physical Anthropology". The Monday morning is devoted to a joint discussion with Section I (Physiology) on "Nutrition and Physique", which should appeal to a wide public. In the afternoon of the same day important communications will be read on "The Affinities of the South African Pleistocene Anthropoids" (Dr. R. Broom) and on "Recent Dis. coveries bearing on Human History in South Africa" (Prof. Raymond Dart). Dr. Broom has sent a collection of casts which will be exhibited at the meet. ings. Two papers of philosophical interest will occupy the latter part of the afternoon: "The Evolution of the Human Brain" (Dr. S. Zuckerman) and "Mental Evolution of the Primates" (Dr. R. H. Thouless).

In the periods given to archxology there will be papers on a recent discovery of cult objects at Grimes Graves (MIr. A. L. Armstrong), an Irish hillsite of the Megalithic Period (Dr. E. E. Evans), the types and chronology of beakers in Spain (Dr. Bosch Gimpera), connexions between the Lake District and Ireland in the Bronze Age (Niss C. Fell), and on the prehistory of Uganda (Prof. C. van Riet Low and Mr. E. J. Wayland). Having special reference to Scotland there will be two papers: "Prospects of the Advancement of Knowledge in Early Scottish History" (Dr. A. O. Anderson), and "Some Recent
Work of the Royal Commission on Ancient Monuments (Scotland)" (Mrr. Angus Graham).

General ethnology is represented by communica. tions dealing with a wooden tea-pot from Tibet (Mr. R. Kerr), racial crossing and cultural efflorescence (Prof. J. Nurphy), the crane dance (Prof. P. E. Newberry), sign language and the education of deaf mutes (Sir Richard Paget), spiritual journeys of the seer (Mrs. N. K. Chadwick), change of personal name among the Biblical Hebrews (Prof. A. II. Honeyman), primitive cults in the religion of the Old Testament (Prof. E. O. James), the wares of a Norocean native doctor (NIr. W. Fogg). A joint discussion with Section I. (Education) on anthropology in education has also been arranged.

In the section dealing with the ethnology of the British Isles there are papers on ballads and tunes which travel (Prof. W. J. Entwhistle), the folklore of death cairns (Miss Maire McNeill), the folklore associated with fishing in the north-east of Scotland (Nrs. 1I. NIcCleod Banks), the human interest of a highland folk-collection (Miss I. F. Grant), and with a survey of some Scottish folklore and its origins (Rev. Canon J. A. NoCulloch). NIrs. Catriona MacKintosh will discuss Hebridean folk-songs, and will sing some of the songs to the accompaniment of the old harp.

\section{Section I (Physiology)}

A LTHOUGH the Physiological and Biochemical A societies each meets nine times every year, yet Section I (Physiology) of the British Association offers certain facilities to physiologists and to biochemists rarely provided by their own societies. These facilities are prearranged discussions on various topics, contact and joint discussion with members of other sections and the opportunity to give publicity to authoritative views on scientific matters of public interest. This is well exemplified by the programme of Section I for the Dundee meeting.

On the Thursday morning, Sections B and I will both hear Prof. E. K. Rideal give his presidential address to Section $B$ on the importance of surface film phenomena in biology. Thereafter, there will be a joint discussion with Section $B$ for the rest of the day on "Tissue Respiration". The subject will be introduced by Prof. R. A. Peters, who convened the discussion. Nine papers will be given. A feature will be the allocation of time for informal discussion of the subject by recognized authorities who have promised to attend.

On Friday morning, Section I will discuss "The Problem of Pain". Very appropriately they will visit St. Andrews for this purpose, where the memory of Sir James Mackenzie, in his day the outstanding authority on the subject, is still fresh in the minds of local workers. In the afternoon there will be visits to the Mackenzie Institute for Clinical Research and to places of scientific and historical interest in the neighbourhood.

On Monday morning there will be a discussion on "Nutrition and Physique" with Section H (Anthropology). Here it is to be expected that the vexed question of "Nature versus Nurture" will receive much attention.

On the Tuesday morning Prof. D. Burns will deliver his presidential address to Section I. His subject is "The Assessment of Physical Fitness". His communication will be followed by a discussion 
on the same topic which will extend into the after. noon.

Both the discussions on the Monday and the Tues. day deal with matters of great importance at the present time. Their scientific interest is equalled only by their practical significance for human welfare. It is to be hoped that many members of the Association, not primarily physiologists, will take the opportunity to be present at these two discussions.

\section{Section J (Psychology)}

$\mathrm{T}$ HE presidential address by Mr. R. J. Bartlett is on measurement in psychology.

Two discussions have been arranged. One is on training the mind. Starting with the old problem of formal training, possible ways of giving a broad and general disciplino will be debated. The other discussion has to do with the use of films in propaganda, entertainment films and public taste, their influence on the child, and so on.

The remaining papers cover most of the fields of psychology. Of broad interest are papers on methodo. logy in psychological medicine, the ego in his world, the primitive nature of poetic genius, and the psychology of frustration. Industrial problems dealt with are the selection of skilled engineering workers, the sorting process in laundries, the analysis of skill by motion study, and the everyday work of a voca. tional adviser; while under mental testing and general experimental psychology come papers on the psycho. logical respectability of physical activity, common sense in music testing, the relations between characteristic interests of schoolboys, the predicting of psychological aptitude in students, experiments on the ultra-perceptive faculty, measures of reliability in group intelligence tests and recent experiments in racial psychology.

\section{Section K (Botany) and Department K* (FORESTRY)}

$\mathrm{T}$

HE president of Section IK (Botany), Prof. D. Thoday, will deal in his presidential address with the "Interpretation of Plant Structure". Captain George I. Campbell, the chairman of $\mathrm{K}^{*}$, will speak on "Forestry in Scotland".

The semi-popular lecture, to be given by Sir Frank Stockdale, will deal with "The Application of Economic Botany in the Tropies". Department K* has organized a special meeting on the larch, and a joint meeting of Section $\mathrm{K}$ and Department $\mathrm{K}^{*}$ will be concerned with local races of trees, seed provenance, and allied topies. The last Tuesday afternoon of the meeting will be given up to the demonstration of exhibits, and the proceedings on that afternoon will finish with the showing of a film, "Coloured Impressions of 'Tweeddale and the Borders" by Miss I. MI. Hayward.

In addition to these special items, Section $\mathrm{K}$ and Department $\mathrm{K}^{*}$ will have before them a comprehensive programme ranging over many aspects of botany and forestry, including a number of com. munications from Scottish workers. The serious labours of the meeting rooms will be varied by excursions to places of interest to botanists and foresters, the chief excursions taking place during the week-end.

\section{Section L (Educational Science)}

FOLLOWING customary practice in recent years the papers to be read before Section L (Educational Science) are grouped around one main theme with two subsidiary themes. The main subject at the Dundee Meetings will be "Education in and for Industry" which will be discussed on the mornings of Thursday, Friday and Monday. Papers will also be read on Monday on recent educational research in Scotland, while on Tuesday there will bo a symposium on the Spens Report.

The President of the Section for 1939 is Dr. A. P. M. Fleming, director of research and training to Metropolitan Vickers Co., and it is fitting in view of the paramount importance that his firm attaches to research and training that his presidential address on Thursday will be on the subject of education for industry. Following the address, papers on aspeets of the same theme will be read by MIr. Lester Smith, Dr. Fisher and Mr. Mouat Jones, who will respectively analyse the part played by local education authorities, public schools and universities in educating those who enter industry at various age-ranges and in various capacities. On Friday, papers will be read on education in industry by Mr. Longmuir of Messrs. Navor and Coulson, and Mr. Darbyshire of the L.MI.S., who will describe schemes of training carried out by industrial firms. The contribution made by technical colleges will be discussed by Mr. C. F. Richardson and Principal Smail of the Heriot-Watt College. Post-advanced courses at the universities will be described by Dr. Willis Jackson.

At Monday's meetings papers will bo read on aspects of industrial education by Mr. Herbert and Dr. Radley who are the chief research officials at the L.M.S. and the G.P.O. respectively. Educational research in Scotland will be discussed by Prof. McClelland and Mr. Hepburn on the same day. Papers on the Spens Report will be read on Tuesday morning by Miss L. Grier, MIr. Henshall, and MIr. J. B. Frizell.

During the meetings the reports of two research committees will bo presented $(a)$ on the organization of educational research (Friday), $(b)$ on the informative content of education (Monday). Visits will be paid on Monday to Perth Academy and on Tuesday to the Dundee Child Guidance Clinic.

\section{Section M (Agriculture)}

THE whole of the programme of Section if (Agriculturo) has been designed to be of immediate practical interest to the farmer, and in all of the discussions which have been arranged, a balance has been kept between recent seientific work and its application in practice. Sir Thomas Middleton will open the proceedings on Thursday with his address entitled "Practice with Science" which will be the keynote for all that follows. Other papers on that morning are "The Breeding and Feeding of Beef Cattle" by Mr. Howie, "Sprouted Fodder in Cattle Feeding" by Principal Paterson, and "Pre-digestion of Coarse Fodders" by Mr. Godden.

Friday morning will be devoted to a discussion on agricultural education to be opened by Mr. MacGregor, who will give an account of some Fife experiments in agricultural education. Mr. Wannop will deal with the organization and working of young farmers' clubs, and Prof. Comber will speak on advisory work in relation to agricultural education and research. 
A subject of immediate practical application, namely, grass conservation, will be discussed on Monday morning. This will be opened by Mr. Martin Jones, who will deal with "The Place of Grassland in Modern Food Production". He will be followed by Dr. Watson, Mr. Roberts and Prof. Kerr, who will speak respectively on the scientific, economic and enginecring aspects of grass conservation.

A subject suited to the locality is that of seed potato growing. A discussion on this will be opened by Mr. Wedderspoon, who will speak as a grower. Virus diseases and seed potatoes will bo considered by Dr. Cockerham, and Dr. McIntosh will deal with the importance of variety in potato production.

An innovation this year is the display of a series of agricultural films by Mr. Miore and Dr. Gordon of the Department of Agriculture of the University of Edinburgh. These will be shown on the Monday afternoon.

\title{
THE INSTITUTE OF MEDICAL AND VETERINARY SCIENCE, ADELAIDE
}

\section{OPENING OF NEW LaBORATORIES}

\author{
By Sir Charles Martin, C.M.G., F.R.S.
}

\begin{abstract}
THE new Institute of Medical and Veterinary Science was officially opened on May 24 by Sir George Murray, Lieutenant-Governor of South Australia and Chancellor of the University of Adelaide. It represents in part an extension and modification of the pre-existing facilities for the study of pathology, bacteriology and biochemistry at the Adelaide Hospital, which is the School of Medicine of the University; in part, it is a new development :
\end{abstract}

(1) To carry out, with more adequate accommodation, equipment and staff than heretofore, the routine investigations in the subjects mentioned above for the Adelaide Hospital, Stock and Brands Department, country hospitals and private practitioners.

(2) To engage in research into the causation, diagnosis and cure of disease in man and animals.

(3) By bringing into a building devoted to these purposes the University teaching departments of pathology, bacteriology and applied physiology, as well as a properly equipped clinical lecture theatre previously wanting in Adelaide, to attempt to inculcate in the medical students that appreciation of the significance of laboratory medicine to which at present comparatively little attention is paid, and thus to render their later outlook more truly scientific.

The Institute will work in the closest collaboration with the Adelaide Hospital on one hand and with the University on the other, and adds greatly to the amenities of the Adelaide Medical School.

The Institute is the result of a joint effort on the part of the University and members of the staff of the Hospital to bring together in closer association the Department of Pathology of the University and the pathological services of the Hospital. As the two institutions adjoin there were no topographical reasons why this should not bo brought about. The Institute is located in the grounds of the Hospital. It faces Frome Avenue, on the opposite side of which is the University campus. It extends backwards amidst the hospital buildings, which are arranged on the pavilion system. It is, therefore, suitably placed for service to the Hospital and readily accessible to patients. It is also close to the other scientific institutes of the University and to the University library. The style is Georgian, with a pleasing simple frontage, and it has been judiciously planned so as to permit of future extension.
In 1936 the authorities wero fortunate in securing Dr. E. Weston Hurst for its first director. Shortly afterwards, the University appointed Dr. Hurst to a research professorship which whilst it gives him the status of a senior officer in the University makes no demands upon the director for teaching duties.

Building was not commenced until 1937, so that the details of planning and equipment were able to bo made under his supervision, and it is clear from the description of the arrangement of the Institute that they have been admirably conceived and carried out. Facilities for research have had due consideration.

The Institute has two stories with a half-basement. It contains some twenty laboratories, a library, two classrooms, a lecture theatre, a complete operating suito for animals, common rooms for staff and students, offices for the director, and an abundant supply of general service rooms (hot room, cold room, photographic suite, etc.), plenty of store rooms and a workshop.

On the first floor is a museum, $80 \mathrm{ft}$. $\times 40 \mathrm{ft}$., to house the collection of specimens of morbid anatomy hitherto inadequately accommodated at the Uni. versity. Perhaps the most notable feature of the Institute is its fine animal house. This is situated 100 yards from the main building. Especial care has evidently been devoted to its construction and equipment for tho breeding of experimental animals and the convenience and accuracy of experimental work. Expense has not been spared for this essential part of an institute for research in pathology, and it cost one tenth as much as the main building.

Tho total cost has been $£ 53,000$. $£ 15,000$ was contributed by three notable benefactions, $£ 10,000$ by the commissioners of charitable funds and the rest by the Government of South Australia.

The Institute is governed by a council of six representing the Adelaide Hospital, the University and the veterinary interests of the State.

The Adelaide Hospital being a Government institu. tion, the surrender of a measure of its sovereignty and some of its territory required a special Act of Parliament. By this Act, the Government undertakes to contribute $£ 10,000$ a year towards the maintenance of the Institute, the remainder being derived from the University Chest and by the allocation of certain 